\title{
HUBUNGAN KECANDUAN GAME ONLINE DAN KETERAMPILAN SOSIAL PADA PEMAIN GAME DEWASA AWAL DI JAKARTA BARAT
}

\author{
Silvia Setiaji ${ }^{1}$ \\ Stefani Virlia ${ }^{2}$ \\ Program Studi Psikologi Universitas Bunda Mulia \\ stefani.virlia@gmail.com
}

\begin{abstract}
Online game is a game that is loved by many people of ages ranging from children to adults. Online games can trigger addiction that can cause effects such as withdrawal, aggressiveness, problems in interpersonal relationships and can even lead to psychological disorders. This study aimed to examine the relationship between online gaming addiction and social skills in early adult game players. The method used is quantitative method and included into the type of correlational research. Respondents in this study is the online game players in the cafe Jakarta Barat, totaling 342 people. The results of this study revealed a significant correlation between addicted to online games and social skills in early adult game players with $r=-0367$ ( $p<0.05)$. Early adult game players have become addicted to the game because it makes online games as an escape from their problems.
\end{abstract}

Keywords : addicted to online game; social skill; , early adulthood

\begin{abstract}
ABSTRAK
Game online adalah permainan yang digemari oleh banyak kalangan usia mulai dari anak-anak hingga dewasa awal. Permainan game online dapat memicu kecanduan yang bisa menimbulkan dampak seperti penarikan diri, agresivitas, masalah dalam hubungan interpersonal dan bahkan dapat mengarah pada gangguan psikologis. Penelitian ini bertujuan untuk melihat hubungan antara kecanduan game online dan keterampilan sosial pada pemain game dewasa awal. Metode penelitian yang digunakan adalah metode kuantitatif dan termasuk ke dalam jenis penelitian korelasional. Responden dalam penelitian ini adalah pemain game online di warnet Jakarta Barat, yang berjumlah 342 orang. Hasil penelitian ini menunjukkan adanya hubungan yang signifikan antara kecanduan game online dan keterampilan sosial pada pemain game dewasa awal dengan $r=-0.367$ ( $\mathrm{p}<0.05$ ). Pemain game dewasa awal memiliki kecanduan terhadap permainan tersebut karena menjadikan game online sebagai pelarian dari masalah yang sedang mereka hadapi.
\end{abstract}

Kata kunci: kecanduan game online; keterampilan sosial; dewasa awal

\section{PENDAHULUAN}

\subsection{Latar Belakang}

Hasil survei majalah Chips tahun 2013 menyebutkan adanya peningkatan pemain game online menjadi 42,8 juta pemain game pada tahun 2015 (Mamduh, 2014) yang tergabung dari berbagai kelompok usia dan gender. Setidaknya 56\% dari populasi pemain game mampu menghabiskan $47 \%$ dari pendapatan mereka untuk membiayai aktivitas game online dan merasa bermanfaat dibandingkan dengan aktivitas hiburan lainnya (Entertainment Sofware Association, 2015).
Alvavnov berpendapat (dalam Widyastuti, 2012) bahwa pemain game online cenderung menghabiskan waktu di game centre atau warnet. Salah satunya di internet cafe (icafe) di Jakarta Barat yang menjadi pelopor warnet yang memiliki lisensi official e-sport di Jakarta yang dikhususkan bagi pemain game online (Agustina Hwang dalam Asmara, 2016)

Permainan game online dapat memicu kecanduan bagi para pemain game online dan pernyataan tersebut sejalan dengan pernyataan ini sejalan dengan Young dan Valiandri 
(Wijayanti, 2013), karena diperkirakan 15 juta pemain game di Indonesia sebagai pecandu game online (Yudhianto dalam Adwitiya \& Suminar, 2015).

Seorang pecandu game online memiliki karakteristik gejala seperti: memiliki perilaku kompulsif, mengalami penarikan diri, kurangnya toleransi, dan adanya masalah pada hubungan interpersonal serta kesehatannya (Chen \& Chang dalam Wulandari, 2015), bermain game online setidaknya lebih dari empat jam/hari selama 3-4 hari berturut-turut dalam seminggu (Yermolayeva, \& Calvert dalam Wijayanti, 2013) atau bermain selama $38.5 \mathrm{jam} / \mathrm{minggu}$ (Young dalam Indahtiningrum, 2013), bermain di warnet minimal enam bulan berurut-turut terhitung dari pertama kali berkunjung ke warnet (Young, dalam Sanditaria, Fitri, Mardhiyah, 2012).

Akibat bagi pecandu game online akan mengalami isolasi sosial, kehilangan kontrol atas waktu, mengalami kesulitan dalam hal akademis, (Fisher; Griffiths, Hunt dalam Loton, 2007), mengembangkan perasaan malu, ketergantungan, depresi, agresi dan narsisme $(\mathrm{Xu}$, Turel \& Yuan, 2012). menurunkan harga diri pemain game (Fisher: Griffths, Hunt dalam Loton, 2007).

Hasil penelitian Cole \& Griffiths (2007) menunjukkan bahwa 20.3\% responden dengan usia rata-rata 23 tahun ke atas mengakui jika game online membawa pengaruh negatif pada aspek relasi dengan orang lain sehingga keterampilan sosialnya menurun (Kim et al., dalam Pratiwi et.al, 2012). Kecanduan game online bersinggungan dengan tinggi rendahnya keterampilan sosial yang dimiliki pemain game, khususnya pada aspek social presentation, social scanning dan social flexibility.

Pengertian keterampilan sosial menurut Wu (2007) adalah sekelompok keterampilan yang digunakan untuk melakukan decoding, mengirim dan mengatur informasi yang masuk secara non verbal dan verbal dalam rangka memfasilitasi interaksi sosial yang positif dan adaptif.

Keterampilan sosial memiliki fungsi seperti mengembangkan kualitas hidup, produktivitas, kesuksesan berkarir, meningkatkan kesehatan fisik, psikologis. Selain itu menjalin persahabatan, memiliki kontrol diri diberbagai situasi sosial (Elksnin \& Elksnin dalam Yanti, 2005).

\subsection{Tujuan Penelitian}

Penelitian ini bertujuan untuk mengetahui hubungan antara kecanduan game online dan keterampilan sosial pada dewasa awal.

\section{TINJAUAN PUSTAKA \\ 2.1 Kecanduan Game Online}

Pengertian dari kecanduan game online menurut beberapa penelitian, kecanduan game diartikan sebagai penggunaan secara berlebih, obsesif, kompulsif dan mengalami masalah umum dari aktifitas bermain game (Charlton \& Danforth; Chiu, Lee, \& Huang; Chou \& Ting; Fisher; Griffiths \& Davies; Grüsser, Thalemann \& Griffiths; Hauge \& Gentile; Ko, Yen, Chen, Chen, \& Yen; Ng \& Wiemer-Hastings; Soper \& Miller; Wan \& Chiou dalam Lemmens, Valkenburg \& Peter, 2009).

Menurut Lemmens, Valkenburg \& Peter (2009) pengertian dari kecanduan game sebagai penggunaan komputer atau smartphone secara berlebihan dan berulang kali yang menghasilkan munculnya permasalahan pada aspek sosial, emosional dan pemain game tidak bisa mengendalikan aktivitas bermain game secara berlebihan.

Komponen kecanduan game online menurut $\mathrm{Wu}$ (2008) terdiri dari 5 komponen yaitu Loss of Control and Consequences, Agitated Withdrawal, Coping, Mournful withdrawal dan Shame. Loss of Control and Consequences adalah kehilangan kontrol diri untuk bermain game online, seperti mendahulukan bermain game online, peningkatan waktu bermain game online sejak pertama kali bermain, kesulitan mengurangi jam bermain game, mengalami konflik pada pekerjaanya/perkuliahannya, konflik interpersonal. Agitated Withdrawal adalah munculnya perasaan tidak menyenangkan seperti marah, cemas karena adanya pengurangan atau dihentikan aktivitas bermain game online dan muncul 
konflik ketika tidak dapat bermain game online. Coping adalah pengalaman subjektif seseorang untuk mengubah perasaan atau untuk melarikan diri dari masalah yang dialaminya dengan bermain game online. Mournful withdrawal adalah perasaan duka, menderita atau kehilangan yang dialami seseorang ketika tidak dapat bermain game online. Shame adalah munculnya rasa penyesalan atas efek negatif akibat dari kurangnya kontrol diri untuk bermain game online.

\subsection{Keterampilan Sosial}

Pengertian keterampilan sosial menurut Riggio (dalam Loton, 2007) adalah sekelompok keterampilan yang digunakan untuk melakukan decoding, mengirim dan mengatur informasi yang masuk secara non verbal dan verbal dalam rangka memfasilitasi interaksi sosial yang positif dan adaptif. Keterampilan sosial dapat diartikan sebagai keterampilan komunikasi, kemampuan berbagi/sharing, untuk melakukan kerja sama dengan orang, berpartisipasi dalam kelompok masyarakat (Seefeldt \& Barbour, dalam Perdani, 2013).

Dimensi keterampilan sosial menurut $\mathrm{Wu}$ (2008) terdiri dari 3 dimensi yaitu: social presentation, social scanning dan social flexibility. Social Presentation adalah keterampilan untuk memahami aturan sosial dengan tepat dan menyesuaikan dirinya dengan peran sosial yang sedang digunakan melalui pesan verbal dan nonverbal yang sesuai dengan norma-norma sosial. Social Scanning adalah keterampilan untuk mendengarkan, mengamati dan mengenali pesan / informasi verbal maupun nonverbal orang lain. Contohnya mengenali isyarat halus untuk mengetahui peran yang tepat dalam situasi tersebut, memeriksa situasi sosial. Social Flexiblity adalah keterampilan yang menyesuaikan perilaku seseorang dari satu peran sosial ke peran sosial yang lain dengan berbagai situasi sosial dengan lancar. Menurut Ferris et al dan Riggio (dalam Wu, 2008) social flexibility sebagai tolak ukur seseorang untuk mengubah perilakunya sesuai dengan berbagai situasi sosial (peran sosial).

\section{METODE PENELITIAN}

Penelitian ini merupakan penelitian korelasional. Subjek penelitian diambil dari populasi pemain warnet game online di Jakarta Barat. Jumlah populasi pemain game online di Jakarta Barat adalah 842.540 orang. . Sampel dalam penelitian berjumlah 342 orang. Subjek penelitian diambil dengan menggunakan metode Probability Sampling dengan teknik Purposive Sampling, teknik ini digunakan untuk pengambilan sampel berdasarkan tujuan yang sudah ditetapkan oleh peneliti (Arikunto, 2010).

Instrumen penelitian ini menggunakan kuesioner GAIA (Game Addiction Inventory for Adult) menurut Ulric Wong \& David Carson (Wong \& Hodgins, 2013). dan SSI (Social Skill Inventory) menurut Yu-Hsien Sharon Wu (Wu, 2008). Berdasarkan dari hasil penghitungan reliabilitas kuesioner GAIA sebesar 0,892 dengan rentang validitas di 0,306 sampai 0,696 , yang terdiri dari 24 item dengan masing-masing item yang tersebar dalam kelima komponen kecanduan game online. Sedangkan hasil yang diperoleh dari hasil penghitungan reliabilitas kuesioner SSI sebesar 0,881 dengan rentang validitas di 0,281 sampai 0,684 , yang terdiri dari 22 item dengan masing-masing item yang tersebar dalam ketiga dimensi keterampilan sosial.

Pemerolehan data yang digunakan dalam penelitian ini, berupa skala likert untuk kedua kuesioner tersebut (dalam Arikunto, 2010), karena peneliti hendak mengukur sikap dan pendapat secara individu. Peneliti melakukan uji kuesioner dan menganalisis data menggunakan teknik analisa pearson karena kedua instrumen terdistribusi normal dan memiliki tujuan untuk mengukur dan menjelaskan arah dan derajat hubungan linear antar dua variabel. 


\section{HASIL DAN PEMBAHASAN}

Berdasarkan dari hasil data yang ditemukan sekitar $46 \%$ dari total respoden berusia 18-20 tahun yang didominasi kaum laki-laki (95\%) dengan mayoritas responden bermain game online dalam 1 hari selama 46 jam (57\%).

Tabel 1. Mean Empirik dan Mean Hipotesis Kecanduan Game Online dan Keterampilan Sosial

\begin{tabular}{llll}
\hline $\begin{array}{l}\text { Kecanduan } \\
\text { Game online }\end{array}$ & \multicolumn{2}{l}{$\begin{array}{l}\text { Keterampilan } \\
\text { sosial }\end{array}$} \\
\hline Mean & Nilai & Mean & Nilai \\
Empirik & 55.89 & Empirik & 62.13 \\
Teoritik & 60 & Teoritik & 55 \\
\hline
\end{tabular}

Kemudian hasil penghitungan analisa diperoleh hasil bahwa respoden memiliki keterampilan sosial yang tinggi dan kecanduan game online yang rendah, hasil tersebut terlihat dari perhitungan mean empirik dan mean teoritik dari kedua kuesioner. Mean empirik dan mean teoritik pada kecanduan game online sebesar 55.89 dan 60 atau bersifat rendah, sedangkan pada keterampilan sosial sebesar 62.13 dan 55 atau bersifat tinggi.

Jika dijabarkan berdasarkan dari komponen-komponen kecanduan game online maka ditemukan komponen loss of control and consequences pada responden rendah (mean empirik $=18.16$ dan mean teoritik $=20$ ), agitated withdrawal pada responden rendah (mean empirik $=8.12$ dan mean teoritik $=10)$, coping pada responden tinggi (mean empirik $=12.30$ dan mean teoritik = 10), mournful withdrawal pada responden rendah (mean empirik $=10.65$ dan mean teoritik $=12.5)$, shame pada responden rendah (mean empirik $=6.66$ dan mean teoritik $=7.5)$. Sedangkan pada komponen keterampilan sosial ditemukan komponen social presentation pada responden tinggi (mean empirik $=27.50$ dan mean teoritik $=25$ ), social scanning pada responden tinggi (mean empirik $=14.58$ dan mean teoritik $=12.5)$, social flexibilty pada responden tinggi (mean empirik $=20.05$ dan mean teoritik $=13.5)$.

Tabel 2. Hasil Korelasi Kecanduan Game Onlie dan Keterampilan Sosial

\begin{tabular}{lc}
\hline & $\begin{array}{c}\text { Hasil Uji } \\
\text { Korelasi }\end{array}$ \\
\hline Pearson Correlation & -0.367 \\
\hline Sig. (2-tailed) & 0.000 \\
\hline
\end{tabular}

Berdasarkan uji korelasi Pearson, didapatkan hasil bahwa terdapat hubungan yang signifikan antara kecanduan bermain game online dan keterampilan sosial pada pemain game dewasa awal di Jakarta Barat ( $\mathrm{p}<0.05$ ). Hubungan antara kedua variabel tersebut dapat dikatakan hubungan yang bersifat lemah dan memiliki hubungan yang negatif. Artinya, ketika kecanduan game online meningkat maka keterampilan sosial menurun, begitu pula sebaliknya.

Bedasarkan dari kelima komponen kecanduan game online, hanya komponen coping yang tinggi pada responden karena responden memainkan game online sebagai sarana untuk melarikan diri dari masalah, untuk mengubah perasaanya,sedangkan keempat komponen lainnya bersifat rendah karena responden merasa bermain game online hanya untuk mengisi waktu luang, pelepas stres, mulai bisa menentukan aktivitas yang harus di prioritaskan dan mulai mampu mengontrol dirinya sendiri.

Meskipun mayoritas responden memiliki kecanduan game online yang rendah, peneliti berhasil menemukan beberapa responden yang mengatakan kalau dirinya kurang memiliki self control yang baik ketika bermain game online diantaranya $18 \%$ respoden mengatakan performa kerja atau kuliahnya menurun, $18 \%$ respoden mengatakan manajemen waktu yang buruk, $11 \%$ respoden mengatakan waktu terbuang sia-sia, $6 \%$ respoden mengatakan menurunnya interaksi secara langung dengan orang lain. Tidak hanya itu, responden juga kesulitan mengontrol emotionalnya seperti mudah merasa bosan 
(27\%), sedih (3\%), merasa kekurangan sesuatu (13\%), dan mudah marah(4\%).

Penemuan tersebut sejalan dengan pendapat Shanahan, Porfeli \& Mortimer (dalam Papalia et.al, 2012) bahwa seseorang dewasa awal seharusnya memiliki memiliki self control dan rasa tanggung jawab pribadi. Jika hal tersebut terjadi maka seseorang akan semakin terikat dan memiliki kecenderungan mengalami kecanduan game online (Griffiths,Davies \& Chappell, dalam Pratiwi et.al, 2012). Salah stau penyebab kehilangan kontrol diri dalam bermain game online karena memberikan efek hiburan (stres relief), tantangan dan permainan yang menarik untuk diselesaikan. Sebab itulah yang membuat pemain tidak mampu mengatur waktu bermain game online (dalam Pratiwi et.al, 2012).

$$
\text { Selanjutnya pada variabel }
$$

keterampilan sosial, ketiga komponen pada responden bersifat tinggi semuanya. Salah satu komponen yang paling mendominasi adalah aspek social flexibility atau mampu menyesuaikan diri dan menempatkan dengan lingkungan baru sesuai dengan peran sosialnya. Kemudian diikuti komponen social presentation atau responden mampu menampilkan dirinya dengan baik dihadapan orang lain dan social scanning atau responden mampu memahami informasi non verbal ketika sedang berinteraksi dengan lawan bicaranya.

Peneliti juga menemukan bahwa 94\% responden merasa memiliki orang terdekat dengan mayoritas teman sebagai jawab responden (56\%). Pernyataan ini dapat disimpulan bahwa responden pada tahap dewasa awal lebih memilih berinteraksi dengan teman-teman kuliah, teman lama atau bertemu secara online melalui permainan game online. Hasil tersebut sesuai dengan pendapat Papalia \& Martorell (2015) bahwa dewasa awal lebih mengandalkan hubungan persahabatannya untuk memenuhi kebutuhan sosialnya terutama pada dewasa awal yang belum menikah.

Ada beberapa faktor yang turut mempengaruhi kedekatan hubungan tersebut seperti memiliki hobi yang sama (28\%), memiliki kesamaan dengan responden (8\%), sebagai teman lama sejak SMP, SMA atau teman kuliah (13\%). Hasil tersebut sejalan dengan pendapat Aizenberg \& Treas (dalam Lemme, 2006) yang mengatakan seseorang dapat menentukan orang terdekatnya bedasarkan dari persamaan umur dan latar belakang. Kedua hal ini yang akan berkontribusi pada kebutuhan, ketertarikan, pengalaman dan perspektif sebuah hubungan seseorang dengan teman dekatnya hingga mampu memperilakukan teman dekatnya seperti keluarga sendiri (Papalia \& Martorell, 2015).

Manfaat dari memiliki teman dekat adalah meningkatkan harga diri seseorang (Blau; Wright dalam Lemme, 2006), sebagai pendengar, pemberi saran dan dukungan ketika menghadapi masalah (Aizenberg \& Treas dalam Lemme, 2006), memberi nilai stimulasi positif, meningkatkan minat dan kesempatan untuk bersosialisasi, memperluas pengetahuan atau perspektif seseorang (Rook; Wright dalam Lemme, 2006).

Peneliti juga menemukan 95\% respoden berjenis kelamin laki-laki. Menurut Cole \& Griffiths (2007) secara umum lakilaki memiliki keinginan kompetitif yang lebih kuat dibandingkan perempuan (Bischof-Koehler; Swain \& Jones dalam Brox, 2011) dan cenderung mengambil resiko lebih tinggi untuk mengalami kecanduan bermain game dibandingkan dengan perempuan (Haugle \& Gentile dalam Brox, 2011).

\section{SIMPULAN DAN SARAN}

Berdasarkan hasil pengujian korelasi, dapat disimpulkan bahwa ada hubungan yang signifikan antara kecanduan bermain game online dan keterampilan sosial pada dewasa awal. Komponenkomponen dari kecanduan game online yang cenderung tinggi adalah komponen coping, karena mayoritas responden menjadikan game online sebagai pelarian atau pelampiasan dari masalah yang sedang mereka hadapi. Pada komponen keterampilan sosial, ketiga aspek cenderung tinggi.

Untuk penelitian selanjutnya mengenai topik penelitian yang terkait, diharapkan dapat mengembangkan karakteristik sampel yang lebih spesifik, 
seperti pemilihan genre game online tertentu dan bisa menambahkan tabel frekuensi responden yang memiliki tingkat kecanduan game online dan keterampilan sosial tinggi, sedang maupun rendah.

Bagi pemain game online, diharapkan untuk terus meningkatkan keterampilan sosial dengan mengikuti organisasi di kampus, beraktifitas bersama teman kerja atau teman baru atau melakukan hobi baru yang lebih bermanfaat. Selain itu memberikan batasan waktu bermain per harinya dengan menyusun jadwal kegiatan sederhana.

Bagi pemilik atau penjaga warnet, dapat memberikan batasan waktu bermain pada pemain dewasa awal maksimal 5-7 jam per hari baik pemain individu maupun kelompok dalam satu warnet tersebut. Pemilik warnet bisa menyediakan ruang sebagai tempat berkumpul sehingga pengunjung warnet dapat menambah koneksi baru, bertemu komunitas baru atau sebagai sarana mencari lowongan pekerjaan.

\section{DAFTAR PUSTAKA}

Angela. (2013). Pengaruh Game Online Terhadap Motivasi Belajar Siswa SDN 015 Kelurahan Sidomulyo Kecamatan Samarinda Ilir. Ejournal Ilmu Komunikasi, 1(2), 532-544.

Arikunto, S. (2010). Prosedur Penelitian Suatu Pendekatan Praktik Edisi Revisi 2010. Jakarta: Rineka Cipta.

Asosiasi Penyelenggara Jasa Internet Indonesia.(2014). Profil pengguna internet di Jakarta Barat. Jakarta: Asosiasi Penyelenggara Jasa Internet Indonesia.

Azwar, S. (2015). Penyusunan Skala Psikologi; Edisi 2. Yogyakarta: Pustaka Pelajar.

Barlett, C.P., Anderson, C. A., \& Swing, E. L. (2009). Video Game Effects Confirmed Suspected and Speculative: A Review of the
Evidence. Simulation \& Gaming, 40(3), 377-403.

Bhawika, A., Suminar, \& Retno, D. (2015). Perbedaan Tingkat Ketergantungan Bermain Game Online di Tinjau dari Persepsi Remaja Terhadap Pola Asuh Orang tua. Psikologi Pendidikan dan Perkembangan, 4 (1), 18-23.

Cole, H., \& Griffiths, M. (2013). Social Interactions In Massively Multiplayer Online Role-Playing Gamers. Cyberpsychology Behavior, 10(4), 575-583.

Godwin, C. J. (2010). Research In Psychology Methods and Design. New York: John Wiley \& Sons, Inc.

Gravetter, F., \& Forzano, L. A. (2012). Research Methods for the Behavioral Science: International Edition. Canada: Wadsworth Cengage Learning.

Hartmann, T., \& Klimmt, C. (2006). Gender and Computer Games: Exploring Females Dislikes. Journal of Computer - Mediated Communication, 11(4), 910-931.

Indahtiningrum, F. (2013). Hubungan Antara Kecanduan Video Game dengan Stres pada Mahasiswa Universitas Surabaya. Jurnal ilmiah mahasiswa Universitas Surabaya, 2(1), 1-17.

King, D. L., Delfabbro, P. H., \& Zajac, I. T. (2011). Preliminary Validation of A New Clinical Tool for Identifying Problem Video Game Playing. Journal of Mental Health and Addiction, 9(1), 72-87.

Lemme, B. H. (2006). Development in Adulthood Fourth Edition. Boston : Allyn and Bacon.

Lemmens, J. S., Valkenburg, P. M., \& Peter, J. (2009). Development and 
Validation of A Game Addiction Scale for Adolescents. Media Psychology, 12 (1), 77-95.

Marius, P., Anggoro, S., \& Content is The King. (2014). Profil pengguna internet Indonesia. Jakarta: Asosiasi Penyelenggara Jasa Internet Indonesia.

Merrell, K. (2008). School Social Behavior Scales: User's Guide Second Edition. Baltimore, MD: Brooks Publishing.

Papalia, D. E., Feldman, R. D., \& Martorell, G. (2012). Experience Human Development. New York: McGraw Hill, Inc.

Papalia, D. E., Olds, S. W., \& Feldman, R. D. (2011). Human Development. New York: McGraw Hill, Inc.

Perdani, P. A. (2013). Peningkatan Keterampilan Sosial Melalui Metode Bermain Permainan Tradisional pada Anak Tk B. Jurnal Pendidikan Usia Dini, 7(2), 335350.

Piliang, Y. A. (2004). Dunia yang Dilipat: Tamasya Melampaui Batas-batas Kebudayaan. Yogyakarta: Jalasutra.

Sanditaria, W., Fitri, S. Y. R., \& Ai, M. (2012). Adiksi Bermain Game Online pada Anak Usia Sekolah di Waring Internet Penyedia Game online Jatinangor Sumedang. Ejournal, 1(1), 1-15.

Soettjipto. (2007). Berbagai Macam Adiksi dan Penatalaksanaannya. Indonesian Pyschological Journal, 23(1), 8490.

Steinkuehler, C. A., \& William, D. (2006). Where Everybody Knows Your Screen Name Games as Third Place. Journal of Computer Mediated Communication, 11(4), 885-909.
Sugiyono. (2011). Metode Penelitian Kuantitatif dan R\&D. Bandung: Alfabeta.

Wan, C. S., \& Chiou, W. B. (2006). Why Are Adolescents Addicted To Online Gaming? An Interview Study In Taiwan. Cyber Psychology and behavior, 9(6), 762-766.

Widyastuti, F. S. (2012). The Study Habits Of Students Play Online Games In Seturan Sleman. E-societas, 1(2), 1120.

Wijayanti, T. W. (2013). Motif dan Adiksi Pemain Game Online: Studi Deskriptif tentang Motif dan Adiksi Pemain Game Online Dragon Nest di Surabaya. Media Commonline, 2(1), 1-11.

Wong, U., \& Hodgins, D. C. (2013). Development of the Game Addiction Inventory for Adults (GAIA). Addiction Research and Theory, 1-15.

Wulandari, R. (2015). Hubungan Antara Kontrol Diri dengan Kecanduan Game Online pada Remaja di Warnet Lorong Cempak Dalam Kelurahan 26 Ilir Palembang. Jurnal Fakultas Psikologi Universitas Bina Darma Palembang, 133, 123-145.

Xu, Z., Turel, O., \& Yuan, Y. (2012). Online Game Addiction Among Adolescents: Motivation and Prevention Factors. European Journal of Information System, 21, 321-340.

Yee, N. (2006). The Demographics, Motivations and Derived Experiences of Users of MassivelyMultiuser Online Graphical Environments. Teleoperators and Virtual Environments, 15, 309-329.

Young, K. S. (2011). CBT-IA: The First Treatment Model for Internet Addiction. Journal of Cognitive Psychotherapy, 25(4), 304-312. 
Asmara, T. (2016). Phoenix eSports Arena, iCafe Nvidia Pertama di Jakarta. Diakses pada 15 Juni 2016 dari tekno.liputan6.com/read/2476484/p hoenix-esports-arena-icafe-nvidiapertama-di-jakarta.

Brox, R. M. (2011). The Influence of Social Factors on Gaming Behaviour, Enschede: University of Twente. Diakses pada 8 Juni 2016 dari http://essay.utwente.nl/60988/1/BSc _R_Brox.pdf.

Elksnin \& Elksnin. (2007). Keterampilan Sosial pada Anak Menengah Akhir. Diakses pada tanggal 5 Maret 2016 dari http://f4jar.multiply.com/journa 1/item/191.

Entertainment Software Association. (2015). Essential Facts About The Computer and Video Game Industry. Diakses pada 25 Maret 2016 dari

http://www.theesa.com/wpcontent/uploads/2015/04/ESAEssential-Facts-2015.pdf.

Feprinca, D. (2014). Hubungan Motivasi Bermain Game Online pada Masa Dewasa Awal Terhadap Perilaku Kecanduan Game Online Defence of The Ancients Dota 2. Diakses pada 2 April 2016 dari http://psikologi.ub.ac.id/wpcontent/uploads/2014/09/JURNAL8. pdf.

Loton, D. (2007). Problem Video Game Playing, Self Esteem and Social Skill: An Online Study, Australia: Victoria University. Diakses pada 6 Juni 2016 dari https://www.researchgate.net/public ation/37376799_Problem_video_ga me_playing_self_esteem_and_social _skills_an_online_study.
Mamduh, M. (2014). Bisnis Game Online Berkembang dan Menggiurkan. Diakes pada 14 Mei 2016 dari http://chip.co.id/news/gamespress_release/9962/bisnis_game_onl ine_berkembang_dan_menggiurkan.

Pratiwi, P. C., Andayani, T. R., \& Karyanta, N. A. (2012). Perilaku Adiksi Game Online Ditinjau dari Efikasi Diri Akademik dan Keterampilan Sosial pada Remaja di Surakarta. Surakarta: Universitas Sebelas Maret Surakarta. Diakses pada 22 Maret 2016 dari http://candrajiwa.psikologi.fk.uns.ac .id/index.php/candrajiwa/article/vie $\mathrm{w} / 27$.

Rolling Into The Southeast Asian Games Market. (2015). Diakses pada 1 Juni 2016 dari https://newzoo.com/wpcontent/uploads/2011/06/Newzoo_P G_Connects_Southeast_Asia_V1.pd f.

Sanditaria, W., Fitri, S. R., \& Mardhiyah, A. (2012). Adiksi Bermain Game Online pada Anak Usia Sekolah di Warung Internet Penyedia Game Online Jatinangor Sumedang. Bandung: Universitas Padjajaran. Diakses pada 22 Maret 2016 dari http://jurnal.unpad.ac.id/ejournal/arti cle/view/745.

Widyanti, N. (2008). Meningkatkan Keterampilan Sosial Siswa Terisolir di Sekolah Dasar dengan Permainan Tradisional. Bandung: Universitas Pendidikan Indonesia. Diakses pada 22 Maret 2016 dari http://eprints.uny.ac.id/14853/1/Nata lia\%20Widyanti_09108244122\%20 ok.pdf.

Wu, Y. H. S. (2008). Social Skill In The Workplace: What is Social Skill and How Does It, Columbia: University of Missouri. Diakses pada 28 Maret 2016 dari https://mospace.umsystem.edu/xmlu 
i/bitstream/handle/10355/5542/resea rch.pdf?sequence $=3$.

Yanti, D. (2005). Ketrampilan Sosial pada Anak Menengah Akhir yang Mengalami Gangguan Perilaku. Diakes pada 18 Maret 2015 dari http://library.usu.ac.id/download/fk/ psikologi-desvi\%20yanti.pdf.

Yusuf, O. (2014). Pengguna Internet Indonesia Nomor Enam Dunia. D iakses pada 13 Maret 2016 dari tekno.kompas.com/read/2014/11/24/ 07430087/pengguna.internet.indone sia.nomor.enam.dunia.

Yuwono, G. T. (2014). Phoenix E-Sport Arena Siap Bantu Kembangkan ESport di Indonesia. Diakses pada 30 Mei 2016 dari http://www.jagatreview.com/2014/0 8/phoenix-e-sport-arena-siap-bantukembangkan-e-sport-di-indonesia/. 